\title{
Bridging the marine-terrestrial disconnect to improve marine coastal zone science and management
}

\author{
Benjamin I. Ruttenberg ${ }^{1, *, * *}$, Elise F. Granek ${ }^{2, * *}$ \\ ${ }^{1}$ National Marine Fisheries Service, Southeast Fisheries Science Center, 75 Virginia Beach Dr., Miami, Florida 33149, USA \\ ${ }^{2}$ Environmental Science and Management, Portland State University, PO Box 751, Portland, Oregon 97207
}

\begin{abstract}
Coastal zone ecosystems sit between larger terrestrial and marine environments and, therefore, are strongly affected by processes occurring in both systems. Marine coastal zone systems provide a range of benefits to humans, and yet many have been significantly degraded as a result of direct and indirect human impacts. Management efforts have been hampered by disconnects both between management and scientific research and across linked marine-terrestrial systems. Management jurisdictions often start or end at the shoreline, and multiple agencies at different levels of government often have overlapping or conflicting management goals or priorities, or suffer from a lack of knowledge or interest. Scientists also often fail to consider connections among linked marine-terrestrial systems, and communication among agencies, among scientists in different disciplines, and between scientists and managers is often inadequate. However, despite the institutional and scientific challenges inherent in improving coastal zone management, there are examples of increased coordination and cooperation among different organizations. We discuss a number of examplesincluding where the marine-terrestrial and science-management disconnects persist and where better integration has led to successes in coastal zone management-and provide recommendations to scientists and managers on how to better link their efforts in science and management across marine and terrestrial systems.
\end{abstract}

KEY WORDS: Nearshore ecosystem · Terrestrial runoff · Marine management · Interdisciplinary science $\cdot$ Florida Keys $\cdot$ California Marine Life Protection Act

\section{INTRODUCTION}

Marine coastal zone ecosystems include intertidal and nearshore marine systems that are influenced by both terrestrial and marine processes. These ecosystems are often particularly sensitive to anthropogenic changes in upstream terrestrial systems and to direct coastal impacts. They include a wide range of habitat types, such as the rocky intertidal, salt marshes, sandy beaches, mangrove forests, soft-bottom bays, coral and rocky reefs, seagrass beds, and kelp forests. They generally occupy a narrow band from the edge of terrestrial systems into the marine realm, and, while they may occasionally influence upstream terrestrial systems, terrestrial impacts on marine coastal zone systems are generally much stronger. Despite the asymmetry of impacts, coastal zone ecosystems provide a suite of essential ecosystem functions to both terrestrial and marine systems (Granek et al. 2010). For example, coastal marine ecosystems serve as nursery habitats for many marine species, filter terrestrial inputs to marine systems, and can accrete new land as well as buffering land from wave impacts (Wahle \& Steneck 1991, Gillanders et al. 2003, Alongi 2008, Cochard et al. 2008, Feagin et al. 2010). Coastal areas also provide a range of other direct benefits to humans, through fisheries, as sources of raw materials, through storm protection, and as areas for recreation (e.g. Koch et al. 2009).

However, because nearly $40 \%$ of human populations live on or near the coasts (Millennium Ecosystem Assessment 2005), these ecosystems often face a range of significant and growing anthropogenic threats (Table 1). Many of these threats are compounded by 


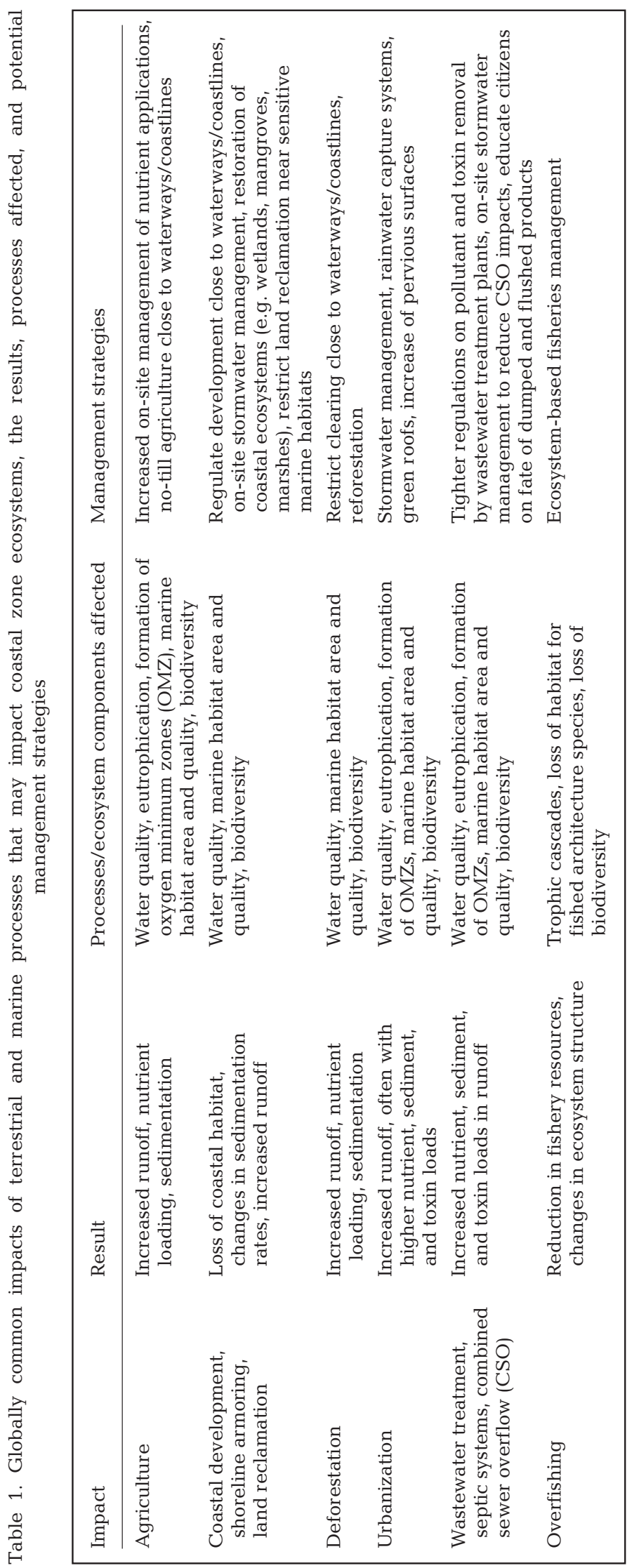

the fact that marine coastal zone ecosystems are tightly connected to both terrestrial and marine realms; changes in adjacent terrestrial or marine systems can alter coastal processes. For example, changes in land-use patterns can alter runoff rates, impacting coastal systems through changes in sedimentation and nutrient inputs, and changes in offshore fisheries can result in cascading trophic effects in coastal zone systems (e.g. Hoffman et al. 1984, Carpenter et al. 1998, Estes et al. 1998, Frank et al. 2005, Diaz \& Rosenberg 2008, Salomon et al. 2010).

Despite the importance of, and threats to, coastal ecosystems, coastal zone management is complicated by the fact that both science and management tend to occur within a 'box.' Marine biologists and ecologists often focus on marine species, communities, and processes, whereas terrestrial biologists and ecologists focus on parallel questions on land. Few scientists examine the connections between terrestrial and marine ecosystems (but see Polis et al. 1997, Gende et al. 2002, Rabalais et al. 2009), and evidence suggests that many ecologists-particularly those working in terrestrial systems-often ignore the literature from other realms (Raffaelli et al. 2005, Stergiou \& Browman 2005, Menge et al. 2009). As a result, we have a poorer understanding of the effects of terrestrial or marine activities on ecological processes in coastal zone ecosystems, and there are fewer data available to assess the potential impacts of a particular stressor or event or their interplay. Similarly, resource managers are usually tasked with addressing impacts inside the boundaries of the areas they manage (either terrestrial or marine) and often lack the authority or the resources to address factors that occur outside their management boundaries. Though some managers are responsible for a suite of ecosystems that straddle both realms, a management area rarely includes an entire watershed that may contribute inputs into nearshore marine and coastal zone ecosystems. Furthermore, managers and agencies may only have jurisdiction over one or the other realm, and their performance goals often end at these boundaries.

Coastal zone ecosystems face additional challenges. First, they are downstream of terrestrial systems. While there are examples of direct marine influences on terrestrial systems (Polis \& Hurd 1996, Dawson 1998, Gende et al. 2002), coastal marine ecosystems are often strongly affected by changes in, and impacts from, terrestrial systems, including land use, nutrient runoff, sedimentation, and other land-based sources of pollution (Millennium Ecosystem Assessment 2005, Rabalais et al. 2009). Marine processes rarely exert strong influences on terrestrial systems, with the exception of unusual events such as storm 
surge or tsunami waves, and impacts from these extreme events are restricted to areas close to the shoreline. Second, most people cannot see changes occurring in the sea because impacts happen below the surface and 'out of sight' for the vast majority of people. Factors such as deforestation, urbanization, and other changes in land-use patterns and declining quality of terrestrial ecosystems are relatively easily observed, whereas similar changes in marine systems, including the effects of such changes in terrestrial systems on coastal zone systems, go unnoticed by the public.

Disparate management strategies, jurisdictions, and research agendas, as well as the 'out of sight' nature of changes to coastal marine ecosystems can lead to a disconnect in both understanding sources and levels of impacts across realms and in effectively managing coastal ecosystem processes, communities, and species. For example, the effects of pollutant loading in rivers has been well studied (e.g. Pereira et al. 1996, Kidd et al. 2007), yet these waters ultimately drain into coastal oceans. We know very little about the levels of land-based contaminants in coastal marine organisms and the effects on their communities and ecosystems (but see Brown et al. 1985, Comeleo et al. 1996). This disconnect can be severe enough to inhibit the success of coastal zone management strategies when inputs from terrestrial or marine ecosystems are not considered or remain unmanaged. As an example, effective fisheries management in the Gulf of Mexico may be insufficient to sustainably manage local populations of shrimp, crabs, and fish as long as nutrient loading from the Mississippi River continues to create 'dead zones' in nearshore waters of the Gulf (Rabalais et al. 2007, Turner et al. 2008). Taken together, these issues make the challenges in coastal zone management 'wicked' problems, in that it can be difficult to define the scope of the problems, let alone determine if or when the problems have been 'solved' (Rittel \& Webber 1973, Jentoft \& Chuenpagdee 2009).

We present cases exemplifying both challenges and successes in coastal zone science and management and attempt to demonstrate the importance of increasing efforts to bridge the marine-terrestrial and science-management disconnects. We also discuss additional strategies that could improve our understanding and management of coastal marine ecosystems through better linking of terrestrial and marine ecosystem practitioners.

\section{THE DISCONNECT: SCIENCE AND MANAGEMENT IN THE FLORIDA KEYS}

The Florida Keys barrier reef system extends $>350 \mathrm{~km}$ from Miami to the Dry Tortugas, $100 \mathrm{~km}$ west of Key
West. The Florida Keys include a wide variety of coastal habitat types, including mangrove forests, extensive seagrass and sand flats, and expansive patch reefs and forereefs that comprise the seaward edge of the barrier reef system, which together host rich biodiversity (Keller \& Causey 2005). There are 80000 year-round residents in the keys, but tourism is the primary industry, with an estimated 3 million annual visitors spending around $\$ 1.2$ billion annually (NOAA 2005). Recreational and commercial fishing provide \$500 million and $\$ 57$ million, respectively, to the local economy (NOAA 2005).

As with many ecosystems with heavy human use, the Florida Keys are beset by a variety of complex threats and challenges from competing interests. Direct impacts to benthic habitats, such as boat groundings, anchor damage, and damage from fishing gear, snorkelers, and divers are increasing. Boat groundings and propellers have damaged $>12000$ ha of seagrass and $>8$ ha of coral reefs (NOAA 2005). Overfishing has also dramatically altered reef fish communities, with a loss of large predators and significant reduction of other economically and ecologically important species (Donahue et al. 2008, McClenachan 2009), and live coral cover on reefs has declined steadily over the past 3 decades (Porter \& Meier 1992, Donahue et al. 2008, Dupont et al. 2008). Eutrophication and sedimentation have increased, at least in part, as a result of the combination of a growing human population and tourism in the Keys and inadequate wastewater and stormwater treatment facilities, as well as decades of change in land-use patterns throughout mainland Florida (Lapointe et al. 2004). Declining water quality may be the most serious issue facing coastal zone ecosystems in the Keys, and is thought to be at least partly responsible for continued loss of live coral, episodic seagrass die-offs, and general decline in the quality of natural resources (Keller \& Causey 2005, but see Precht \& Miller 2007).

Addressing any of these issues would be difficult for management agencies under ideal conditions, but the situation in the Florida Keys is far more complicated. Impacts originate from both marine and terrestrial sources, and the Keys are managed by a suite of different organizations and agencies at different levels of government with differing and overlapping jurisdictions and missions that are not always fully aligned (Fig. 1). Spatial management in the Florida Keys is overseen by 5 federal agencies in 2 different cabinet departments and at least 3 state agencies, including: the Florida Keys National Marine Sanctuary of the National Oceanic and Atmospheric Administration (NOAA) in the US Department of Commerce; 3 different National Parks of the National Park Service and 4 National Wildlife Refuges of the US Fish and Wildlife 


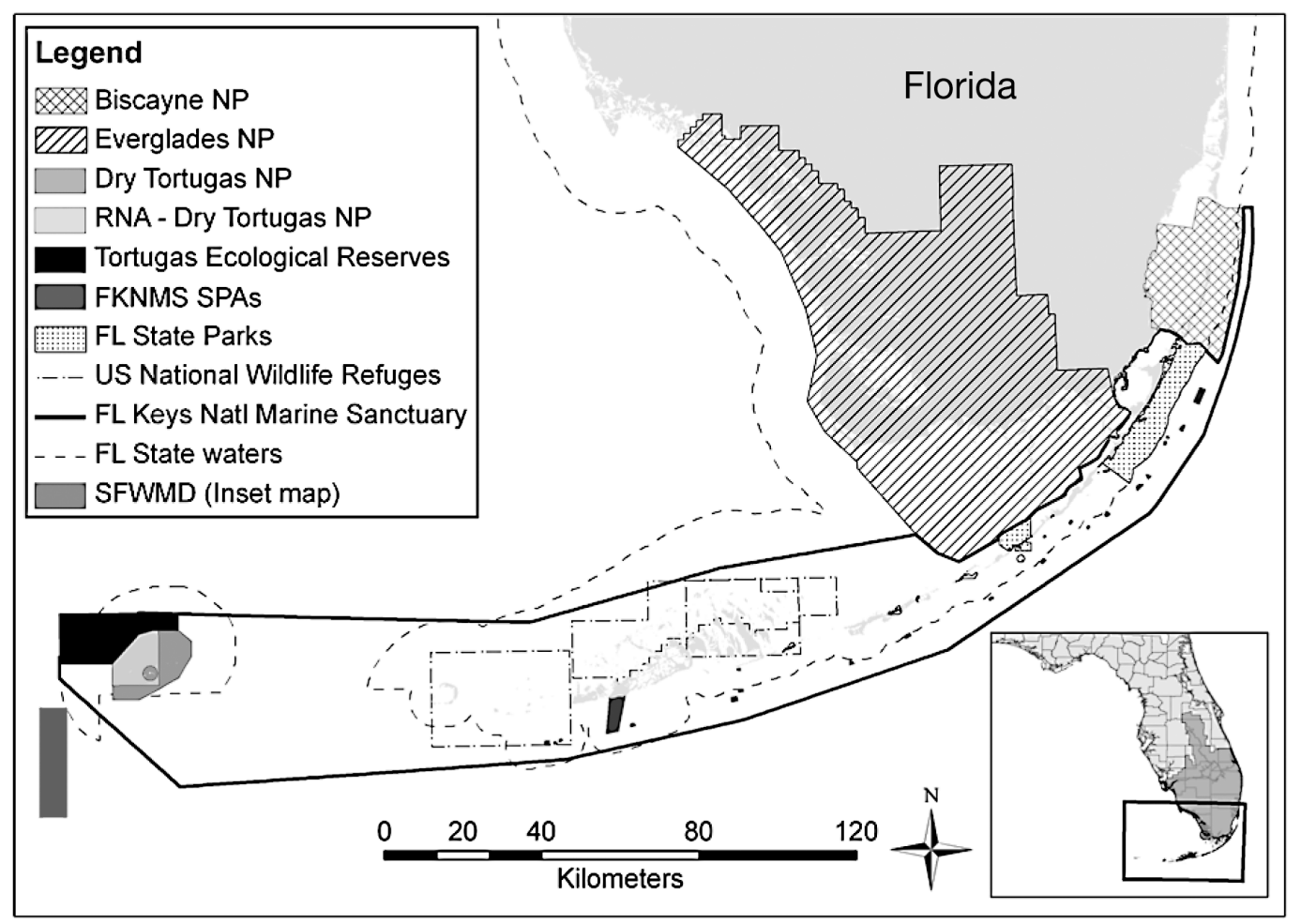

Fig. 1. Map of the Florida (FL) Keys, showing management zones and overlapping jurisdictions of multiple state, federal, and local agencies responsible for management. NP: National Park; RNA: Research Natural Area, a no-take zone within Dry Tortugas NP; SPAs: Sanctuary Preservation Areas, no-take zones within the Florida Keys National Marine Sanctuary (FKNMS); SFWMD: South Florida Water Management District, the state agency responsible for water management in the Everglades, Florida Bay, and Florida Keys watershed, shown in dark gray on inset map with county boundaries

Service, both agencies in the US Department of the Interior; a research natural area, a no-fishing and noanchoring zone in Dry Tortugas National Park reauthorized every $5 \mathrm{yr}$ by a Board of Trustees comprised of Florida's Governor and Cabinet; and 6 state parks, administered by the Department of Environmental Protection of the State of Florida. Fishery regulations in state waters (within 3 miles of land in the Atlantic, 9 miles in the Gulf of Mexico) are set by the Florida Fish and Wildlife Conservation Commission (FWC), whereas fishery regulations in federal waters are set by the South Atlantic Fishery Management Council in the Atlantic, and the Gulf of Mexico Fishery Management Council on the Gulf of Mexico and Dry Tortugas. Federal fishing regulations are administered by the National Marine Fisheries Service of NOAA, and generally match those of the state, but they do not always coincide (e.g. FWC 2010, SAFMC 2010). There are a range of user groups and stakeholders that influence public policy and management priorities in the Keys; these include year-round and seasonal residents, tourists, the tourism industry, recreational and commercial fishing interests, SCUBA operators, and conservation groups. In addition, there are a variety of additional state, county, and municipal agencies in upstream areas of mainland South Florida whose land- and water-use policies can strongly influence the Florida Keys, such as the Environmental Protection Agency, the Florida Department of Environmental Protection, the South Florida Water Management District, and many others (Fig. 1).

The wide variety of threats, management agencies, and stakeholders make it extremely difficult to effectively prioritize resources for science and management. As in many other systems, many scientists working in the Keys are focused on a single system-either terrestrial or marine-and many researchers (including the authors of the present paper) focus their efforts on only a few habitats or taxonomic groups. Both personal and institutional biases are responsible; most ecologists are trained to study only subsets of systems, and many funding agencies, especially those responsible for managing aspects of the Florida Keys, are interested in questions that address specific management needs and goals. Requests for proposals with specific objectives generate narrowly focused research projects designed to answer specific management questions.

Not surprisingly, most management agencies and managers are focused on their specific systems as well. They usually lack sufficient personnel and financial 
resources to address the most pressing and urgent needs that confront them on a daily basis, let alone to tackle large-scale threats that originate from outside their jurisdiction. As a result, a number of problems remain unmitigated, and even simple steps towards potential solutions have not been implemented. For example, fishing pressure remains extremely high in the Keys, and 24 of 29 species in the snapper-grouper complex are overfished and/or undergoing overfishing (Ault et al. 2005), and the small no-take reserves in the Keys that include only $6 \%$ of the hard-bottom habitat in the Keys (Smith et al. 2011) are too small to recover these populations. Staff at Biscayne National Park, at the northern end of the Florida Keys, have been considering including a no-take fishing zone in the management plan for over a decade, but have been unable to implement such a zone (in the National Park) for a variety of reasons, including resistance from some stakeholders, overlapping jurisdictions with other agencies, the daily challenges of managing a large marine park, and the lack of resources for implementation. Cover of live coral, the primary source of reef accretion throughout the Keys, has declined precipitously and remains low throughout the Keys (Donahue et al. 2008, Dupont et al. 2008), and water quality continues to be a problem (Lapointe et al. 2004, Keller \& Causey 2005).

However, in spite of the many difficulties of conducting comprehensive science and management, there are positive steps towards integration. The Comprehensive Everglades Restoration Plan (CERP; www. evergladesplan.org) is a large multi-agency project designed to restore water flow and ecosystem function to the greater Everglades ecosystem, covering $>4.5$ million ha. It is funded by the state legislature and the United States Congress, and was designed to be implemented over a $30 \mathrm{yr}$ period. Among its many goals, CERP explicitly seeks to restore some historical water flows and reduce nutrient inputs into Florida Bay, reducing anthropogenic nutrient inputs to the Florida Keys reef system (Keller \& Causey 2005). The National Science Foundation (NSF) has bolstered related scientific efforts by funding the Florida Coastal Everglades Long-Term Ecological Research (FCE LTER), a project that includes 72 senior scientists from 31 institutions (fce.lternet.edu). The FCE LTER examines the connections between freshwater and marine systems within the greater Everglades ecosystem and investigates how anthropogenic disturbance (and restoration) to this system affects ecological processes. Furthermore, recognizing the effects of sewage on nearshore marine ecosystems, municipalities in the Keys are restricting use of septic tanks. In 1990, there were > 25000 septic tanks and 9000 cesspits in the Keys. By 2011, 70\% of households are planned to be on a central sewage system (Sleasman 2009, B. Causey pers. comm.). Imple- menting these projects required strong communication and coordination among a diverse group of agencies from all levels of government, appropriations from the state and federal legislatures, and a long-term outlook.

The Florida Keys exemplify many of the issues facing coastal zone management: diverse threats and challenges; multiple stakeholders; complex, overlapping jurisdictions administered by multiple state and federal agencies; and a number of scientists and managers focusing on individual, disparate aspects of the larger problem, often with little effective communication among them. Despite these significant and varied impediments to effectively link science and management across ecosystems, there are signs of increased collaboration and cooperation across ecosystems and disciplines.

Other areas face similar challenges. The Chesapeake Bay, the largest estuary in the USA, is in poor condition, degraded by habitat loss, overfishing, and reductions in water quality from changes in land use, bay habitats, and ecological processes. The watershed encompasses parts of 6 states and a variety of federal and state management agencies. One of the most critical and most difficult issues is runoff; nearly $25 \%$ of the land in the watershed is agricultural, and increased sedimentation, nutrient inputs, and pollutants from these operations are extremely difficult to manage (USGS 2003). A public-private partnership, the Cheseapeake Bay Program, was created to facilitate communication and restoration efforts among stakeholders, but despite progress, the bay remains in poor condition (Chesapeake Bay Program 2009).

The coastal zones of the Gulf of Mexico have also suffered from habitat loss and a variety of natural and anthropogenic impacts. Oxygen minimum zones appeared near the mouth of the Mississippi River decades ago. These have been linked to anthropogenic activities and have been increasing in size (Turner et al. 2008). The issues in the Gulf of Mexico are particularly challenging because the Gulf borders 5 states, and the Mississippi River watershed encompasses $>40 \%$ of the land area of the continental United States, making coordinating science and management of the downstream coastal systems extremely difficult (Turner \& Rabalais 1991).

In these examples, many of the most daunting challenges are institutional; multiple institutions are involved from a host of different federal, state, and local agencies, each with its own set of missions, constituents, and stakeholders. Coordinating and aligning goals and incentives either horizontally or vertically becomes an almost impossible task, with the result that little effective management is achieved (Lafferty \& Hovden 2003). Furthermore, there is little or no legislation or funding appropriated to provide the legal framework and financial incentives to induce or force different institutions to coordinate efforts and align goals. 


\section{CONNECTING TERRESTRIAL AND MARINE SCIENCE FOR COASTAL ZONE MANAGEMENT: THE SANTA BARBARA CHANNEL AND CALIFORNIA COASTAL RESERVES}

Like many coastal areas around the globe, the nearshore coastal ecosystems in California have been significantly impacted by human activities. California has lost $>90 \%$ of its coastal wetlands since European colonization (California Natural Resources Agency 2010), once-abundant large fish such as giant sea bass Stereolepis gigas have been overfished and are listed as critically endangered by the IUCN (Cornish 2004, California Department of Fish and Game 2010), and many ecological dynamics in nearshore kelp forests have been fundamentally changed by human activities (e.g. Dayton et al. 1998). Because of these issues, scientists and managers throughout the state have been collaborating across agencies and disciplines to improve coordination in science and management of California's coastal zones.

In 2000, the NSF funded the Santa Barbara Coastal LTER (SBC LTER), designed explicitly to study the connections between, and the effects of, human activities on terrestrial, estuarine, nearshore, and oceanic ecosystems (sbc.lternet.edu). A team of $>35$ academic investigators from 6 institutions examine the effects of land-use changes and other human impacts on the transport of nutrients, sediment, toxicants, and organisms across landscapes and their influences on coastal and nearshore ocean processes and ecosystems. In addition, these academic investigators collaborate with over 10 federal, state, local, and non-profit agencies and organizations to determine how to use this information to guide management and public policy.

Other policy initiatives have successfully integrated terrestrial and marine science into coastal management statewide. As early as 1976, the state of California established the California Coastal Commission, an independent state agency charged with regulating the use of both land and water in the coastal zone to 'protect, conserve, restore, enhance environmental and human-based resources of the California coast and ocean for environmentally sustainable and prudent use by current and future generations' (www.coastal.ca. gov/whoweare.html). To further strengthen coastal protection and conservation, the California legislature passed the Marine Life Protection Act (MLPA) in 1999 (Osmond et al. 2010). This act explicitly recognizes that 'coastal development, water pollution, and other human activities threaten the health of marine habitats and the biological diversity found in California's ocean waters' (Marine Life Protection Act, 2008; www.dfg. ca.gov/mlpa/pdfs/revisedmp0108a.pdf), and mandates the creation of a network of marine protected areas
(MPAs) throughout the state. Furthermore, the act states that the network of MPAs will be based on sound scientific guidelines, including biogeography, habitat representation, and spacing, MPA size and spacing, water quality, and fishery impacts (California MLPA Master Plan Science Advisory Team 2011). A publicprivate partnership was formed to guide the process, with funding from state and private sources. The state was divided into 5 regions, each with a science advisory team, a regional stakeholders group, and a statewide interests group. Members in each of these groups were drawn from a wide range of interests, industries, and agencies, including recreational and commercial fishing associations, tour operators, conservationists, state, federal, and local agencies, and academia. As of May 2010, MPAs have been implemented and enforced in 2 of the 5 regions; the process is underway in 2 additional regions, and will begin in the final region in 2011 (www.dfg.ca.gov/mlpa/).

A related process to implement MPAs in the California Channel Islands preceded the MLPA process. The effort to create MPAs in the Channel Islands was driven not by legislative mandates as in the MLPA process, but instead by local stakeholders with the involvement of federal and state agencies, guided by the California Department of Fish and Game (CDFG). The northern Channel Islands also overlap with the Channel Islands National Park (administered by the National Park Service, United States Department of the Interior), but fishing regulations are set and enforced by the CDFG. This process resulted in the creation of a network of MPAs in state waters around the Channel Islands in 2003, many of which are located in the Channel Islands National Park (Osmond et al. 2010). The Channel Islands National Marine Sanctuary, which encompasses federal waters around the northern Channel Islands, was granted the appropriate regulatory authority in 2007 and subsequently implemented a series of federal MPAs adjacent to the existing MPAs in state waters, essentially expanding the state MPAs. While not without challenges and difficulties, these processes considered the viewpoints of a wide variety of stakeholders and integrated science into the planning process; plans succeeded despite the absence of a legislative framework, in part, because of the close coordination among stakeholders and the relatively small number of participants (Osmond et al. 2010).

In both the MLPA process and in the Channel Islands, scientists played a major role in guiding the discussion to ensure the final plans were scientifically rigorous. Much of the scientific information included existing data on distribution and abundance of marine organisms. The planning process also considered terrestrial-coastal-marine connectivity and land-use patterns (more so for the MLPA process, since the Chan- 
nel Islands are mostly uninhabited by humans); many MLPA reserves have been placed adjacent to existing terrestrial reserves, where land development and terrestrial influences from anthropogenic sources are likely to be minimized (Gleason et al. 2010). Finally, by recognizing the importance of nearshore coastal processes and the fact that many species use a variety of habitats, both processes to implement MPAs in the Channel Islands and throughout the remainder of the state considered the full suite of available habitats, from the shoreline to deep water. At the same time, implementation plans for these new reserves considered adjacent terrestrial areas, but the process did not require changes in land use or other terrestrial modifications for successful implementation of MPAs. Therefore, no major modifications - or major involvementfrom terrestrial management agencies were required, which significantly reduced the number of stakeholders and greatly simplified the process. Efforts to address other resource management issues that span marine and terrestrial systems in the state, such as those to manage the San Francisco Bay delta, have been less successful, in part because of the complexity of the problem, the number of stakeholders and agencies involved, and the changes needed in upstream areas (Gerlak \& Heikkila 2006).

\section{KEYS TO SUCCESSFUL INTEGRATION OF COASTAL ZONE SCIENCE AND MANAGEMENT}

Successful and effective coastal zone management continues to be difficult to implement across the USA and throughout the world. Despite these challenges, there are signs of increasing integration across marine and terrestrial systems and progress in coastal zone science and management. Multi-agency and multiinstitution research and engineering projects, guided by state and federal mandates and appropriations, are underway to restore historical water flow patterns in the Everglades that will improve Florida Bay and Florida Keys ecosystems. Transparent, inclusive MPA planning processes, often guided by legislation, have led to the implementation of science-based networks of MPAs that account for land use in California, and large-scale research projects are underway that are explicitly designed to study the impacts of terrestrial inputs and land use on nearshore coastal ecology. In Puget Sound, the state of Washington created the Puget Sound Partnership, a state agency tasked with overseeing management and restoration efforts in Puget Sound, including coordinating the scientific research needed to guide the process (Puget Sound Partnership 2010). The scientific priorities explicitly include tracing the sources and effects of terrestrial inputs in this heavily urbanized watershed, and management priorities include the ultimate goals of mitigating these impacts. In SW Puerto Rico, changes in Gúanica Bay and its associated watersheds have led to significant declines in water quality and the condition of nearshore reefs. To restore the historical functions of the watershed and bay, a series of major multi-year projects were initiated in 2009 by the NOAA and United States Department of Agriculture in response to a watershed management plan (Center for Watershed Protection 2008). These projects include restoration of drained freshwater lagoons and planned reductions in runoff and sedimentation into the bay from upstream agriculture. If successful, it will serve as an excellent model for conducting effective coastal zone management across linked marine-terrestrial systems.

Other agencies have also begun to recognize the importance of science and management in linked marine-terrestrial systems. The NSF funds a biocomplexity program entitled 'Dynamics of Coupled Natural and Human Systems', which seeks to fund research projects that include anthropogenic effects on biological systems. The NOAA's Coral Reef Conservation Program has identified 3 primary threats to coral reef ecosystems, one of which is land-based sources of pollution. This program devotes a significant amount of its funding to projects that study or mitigate land-based sources of pollution, including comprehensive watershed management plans. In addition, the Interagency Ocean Policy Task Force recently released a report recommending that the United States government develop a framework for comprehensive coastal and marine spatial planning (Anon 2010). These recommendations, adopted by the United States government, include considerations of terrestrial inputs to marine systems, and the entire process is to utilize science-based information in all decision-making.

However, despite some successes and an increased recognition of the importance of coastal ecosystems and the marine and terrestrial systems that affect them, enormous challenges remain. To continue moving science and management towards better integration, we make a number of recommendations to management agencies and scientists.

Recommendations to the agencies:

(1) Consider a system as a whole, including processes occurring in upstream terrestrial areas and impacts in downstream coastal zones, using ecosystem-based approaches. Watersheds and activities occurring on land upstream of coastal systems will affect downstream areas, and in many cases it will be impossible to effectively manage coastal systems without both understanding and managing terrestrial inputs.

(2) Governance. Provide legislative frameworks, mandates, and appropriations by using legislation or 
agency rule-making to create the needed legal guidelines to improve coordination, including linking funding to meaningful progress. The more complex a management situation, the more critical legislation is to make positive progress.

(3) Interagency communication. Maintain clear, open, and frequent communication among agencies and across management levels, particularly with respect to management goals. Create incentives to encourage interagency collaboration, including interagency working groups and task forces.

(4) Align management goals. Different agencies will act together most effectively when their individual goals match. If goals do not match, seek to modify them or seek more restricted common areas where small amounts of progress are possible.

(5) Transparency and participatory processes. Regulatory processes must be transparent and inclusive to keep stakeholders involved and supportive. At the same time, reducing the number of organizations involved may increase the likelihood of consensus.

(6) Include the best science, and allow scientists to help guide the process. Science can make compelling and defensible arguments as to why action is needed and what impact it will have. The resource management process will not be successful without policy grounded in solid science, and solid scientific information can be used to motivate both public opinion and legislators.

Recommendations to the science community:

(1) Think broadly and holistically. Consider how a particular study system might influence and be affected by other systems, and incorporate ideas from the literature on other systems.

(2) Talk to and collaborate with colleagues from other disciplines. Different ideas can inspire new perspectives and novel approaches to questions; many scientists pay lip-service to this idea, but few follow through in practice.

(3) Consider large-scale inclusive projects that span systems and disciplines. Projects such as NSF-funded LTER programs and Dynamics of Coupled Natural and Human Systems are necessary, important, and fundable, as are multi-disciplinary data synthesis projects.

(4) Communicate with managers and policymakers, not just other scientists. Most managers want to know more about how the systems for which they are responsible function, and often welcome such input when presented objectively.

(5) Science can support and guide management. Collaborations among scientists from different disciplines can facilitate more holistic management. Scientists can also influence and guide bottom-up policy processes through integrated research and appropriate presentation of findings, and ultimately influence the creation and direction of top-down (e.g. legislated or agency rule) management processes.

Ultimately, environmental scientists must get involved and take a leadership role in driving the search for solutions to the various 'wicked' coastal environmental problems. In many cases, managers are so limited in time and resources that they are unable to approach problems as broadly and comprehensively as needed. These limitations are often compounded by institutional constraints imposed by multiple overlapping agencies or limited managerial or jurisdictional authority. Scientists, on the other hand, are often free from some of these constraints, and have a responsibility to study problems objectively, ask compelling questions, and provide evidence that managers need to effect change. Collaborative research that crosses disciplinary and marine-terrestrial boundaries can highlight new issues and approaches. Advancing coastal zone science can guide coastal management, resulting in a better understanding of coastal systems and better stewardship of their resources.

Acknowledgements. We thank J. Bohnsack, J. Schull, J. Serafy, and 4 anonymous reviewers for helpful discussions and useful feedback on earlier drafts that greatly improved this manuscript, and J. Blondeau for assistance mapping the complex jurisdictions of the Florida Keys. Thanks to M. Solan for the invitation to participate in this Theme Section. Open Access for the Theme Section on Coastal Zone Management is sponsored by the Marine Alliance for Science and Technology for Scotland (MASTS) Coastal Zone Joint Research Theme.

\section{LITERATURE CITED}

Alongi DM (2008) Mangrove forests: resilience, protection from tsunamis, and responses to global climate change. Estuar Coast Shelf Sci 76:1-13

Anonymous (2010) Final recommendations of the Interagency Ocean Policy Task Force. White House Council on Environmental Quality. Available at: www.whitehouse.gov/ files/documents/OPTF_FinalRecs.pdf (accessed on 8 November 2010)

Ault JS, Bohnsack JA, Smith SG, Luo JG (2005) Towards sustainable multispecies fisheries in the Florida, USA, coral reef ecosystem. Bull Mar Sci 76:595-622

Brown RC, Pierce RH, Rice SA (1985) Hydrocarbon contamination in sediments from urban stormwater runoff. Mar Pollut Bull 16:236-240

California Department of Fish and Game (2010) Status of the fisheries report: an update through 2008. Available at: www.dfg.ca.gov/marine/status/report2008/entire.pdf (accessed on 7 November 2010)

California MLPA Master Plan Science Advisory Team (2011) Methods used to evaluate Marine Protected Area proposals in the North Coast Study Region. Marine Life Protection Act Initiative, Sacramento, CA. Available at: www.dfg.ca. gov/mlpa/pdfs/northcoastproposals/evaluationmethods. pdf (accessed on 2 March 2011)

California Natural Resources Agency (2010) State of the 
state's wetlands: 10 years of challenges and progress. Available at: http://resources.ca.gov/ocean/SOSW_report. pdf (accessed on 7 November 2010)

Carpenter SR, Caraco NF, Correll DL, Howarth RW, Sharpley AN, Smith VH (1998) Nonpoint pollution of surface waters with phosphorus and nitrogen. Ecol Appl 8:559-568

Center for Watershed Protection (2008) Guánica Bay Watershed Management Plan: a pilot project for watershed planning in Puerto Rico. Center for Watershed Protection, Elliot City, MD

Chesapeake Bay Program (2009) Bay barometer: a health and restoration assessment of the Chesapeake Bay and Watershed in 2009. Chesapeake Bay Program, Annapolis, MD. Available at: www.chesapeakebay.net/content/publications/cbp_50513.pdf (accessed on 10 November 2010)

> Cochard R, Ranamukhaarachchi SL, Shivakoti GP, Shipin OV, Edwards PJ, Seeland KT (2008) The 2004 tsunami in Aceh and southern Thailand: a review on coastal ecosystems, wave hazards and vulnerability. Perspect Plant Ecol Evol Syst 10:3-40

- Comeleo RL, Paul JF, August PV, Copeland J, Baker C, Hale SS, Latimer RW (1996) Relationships between watershed stressors and sediment contamination in Chesapeake Bay estuaries. Landscape Ecol 11:307-319

Cornish A (2004) Stereolepis gigas. IUCN 2010: IUCN Red List of Threatened Species, Vers 2010.4. Available at: www.iucnredlist.org (Accessed 7 November 2010)

$>$ Dawson TE (1998) Fog in the California redwood forest: ecosystem inputs and use by plants. Oecologia 117: 476-485

Dayton PK, Tegner MJ, Edwards PB, Riser KL (1998) Sliding baselines, ghosts, and reduced expectations in kelp forest communities. Ecol Appl 8:309-322

Diaz RJ, Rosenberg R (2008) Spreading dead zones and consequences for marine ecosystems. Science 321:926-929

Donahue S, Acosta A, Akins L, Ault J and others (2008) The state of coral reef ecosystems in the Florida Keys. In: Waddell JE, Clarke AM (eds) The state of coral reef ecosystems of the United States and Pacific Freely Associated States: 2008. NOAA/NCCOS Center for Coastal Monitoring and Assessment Team, Silver Spring, MD, p 161-188

Dupont JM, Jaap WC, Hallock P (2008) A retrospective analysis and comparative study of stony coral assemblages in Biscayne National Park, FL (1977-2000). Caribb J Sci 44: $334-344$

Estes JA, Tinker MT, Williams TM, Doak DF (1998) Killer whale predation on sea otters linking oceanic and nearshore ecosystems. Science 282:473-476

Feagin RA, Mukherjee N, Shanker K, Baird AH and others (2010) Shelter from the storm? Use and misuse of coastal vegetation bioshields for managing natural disasters. Conserv Lett 3:1-11

Frank KT, Petrie B, Choi JS, Leggett WC (2005) Trophic cascades in a formerly cod-dominated ecosystem. Science 308:1621-1623

FWC (Florida Fish and Wildlife Conservation Commission) (2010) Florida fishing regulations: saltwater edition. FWC, Tallahassee, FL. Available at http://myfwc.com/fishing/ saltwater/regulations/ (accessed on 10 November 2010)

Gende SM, Edwards RT, Willson MF, Wipfli MS (2002) Pacific salmon in aquatic and terrestrial ecosystems. Bioscience 52:917-928

Gerlak AK, Heikkila T (2006) Comparing collaborative mechanisms in large-scale ecosystem governance. Nat Resour J 46:657-707

Gillanders BM, Able KW, Brown JA, Eggleston DB, Sheridan
PF (2003) Evidence of connectivity between juvenile and adult habitats for mobile marine fauna: an important component of nurseries. Mar Ecol Prog Ser 247:281-295

Gleason M, McCreary S, Miller-Henson M, Ugoretz J and others (2010) Science-based and stakeholder-driven marine protected area network planning: a successful case study from north central California. Ocean Coast Manag 53:52-68

Granek EF, Polasky S, Kappel CV, Reed DJ and others (2010) Ecosystem services as a common language for coastal ecosystem-based management. Conserv Biol 24:207-216

- Hoffman EJ, Mills GL, Latimer JS, Quinn JG (1984) Urban runoff as a source of polycyclic aromatic hydrocarbons to coastal waters. Environ Sci Technol 18:580-587

Jentoft S, Chuenpagdee R (2009) Fisheries and coastal governance as a wicked problem. Mar Policy 33:553-560

Keller BD, Causey BD (2005) Linkages between the Florida Keys National Marine Sanctuary and the South Florida Ecosystem Restoration Initiative. Ocean Coast Manag 48: 869-900

Kidd KA, Blanchfield PJ, Mills KH, Palace VP, Evans RE, Lazorchak JM, Flick RW (2007) Collapse of a fish population after exposure to a synthetic estrogen. Proc Natl Acad Sci USA 104:8897-8901

Koch EW, Barbier EB, Silliman BR, Reed DJ and others (2009) Non-linearity in ecosystem services: temporal and spatial variability in coastal protection. Front Ecol Environ 7: 29-37

Lafferty WM, Hovden E (2003) Environmental policy integration: towards an analytical framework. Environ Polit 12: $1-22$

> Lapointe BE, Barile PJ, Matzie WR (2004) Anthropogenic nutrient enrichment of seagrass and coral reef communities in the Lower Florida Keys: discrimination of local versus regional nitrogen sources. J Exp Mar Biol Ecol 308: $23-58$

McClenachan L (2009) Documenting loss of large trophy fish from the Florida Keys with historical photographs. Conserv Biol 23:636-643

Menge BA, Chan F, Dudas S, Eerkes-Medrano D and others (2009) Terrestrial ecologists ignore aquatic literature: asymmetry in citation breadth in ecological publications and implications for generality and progress in ecology. J Exp Mar Biol Ecol 377:93-100

Millennium Ecosystem Assessment (2005) Ecosystems and human well-being: current state and trends, Vol 1. Island Press, Washington, DC

NOAA (National Oceanic and Atomospheric Administration) (2005) Florida Keys National Marine Sanctuary draft, revised management plan. Available at: http://floridakeys.noaa.gov/regs/5yearreview/docs/volunteer_322.pdf (accessed on 10 November 2010)

> Osmond M, Airame S, Caldwell M, Day J (2010) Lessons for marine conservation planning: a comparison of three marine protected area planning processes. Ocean Coast Manag 53:41-51

Pereira WE, Domagalski JL, Hostettler FD, Brown LR, Rapp JB (1996) Occurrence and accumulation of pesticides and organic contaminants in river sediment, water and clam tissues from the San Joaquin River and tributaries, California. Environ Toxicol Chem 15:172-180

Polis GA, Hurd SD (1996) Linking marine and terrestrial food webs: allochthonous input from the ocean supports high secondary productivity on small islands and coastal land communities. Am Nat 147:396-423

> Polis GA, Anderson WB, Holt RD (1997) Toward an integration of landscape and food web ecology: the dynamics 
of spatially subsidized food webs. Annu Rev Ecol Syst 28: 289-316

Porter JW, Meier OW (1992) Quantification of loss and change in Floridian reef coral populations. Am Zool 32:625-640

Precht WF, Miller SL (2007) Ecological shifts along the Florida Reef Tract: the past as a key to the future. In: Aronson RB (ed) Geological approaches to coral reef ecology. Springer, New York, NY, p 237-312

Puget Sound Partnership (2010) Strategic science plan. Puget Sound Partnership, Olympia, WA

Rabalais NN, Turner RE, Sen Gupta BK, Boesch DF, Chapman P, Murrell MC (2007) Hypoxia in the northern Gulf of Mexico: Does the science support the plan to reduce, mitigate, and control hypoxia? Estuaries Coasts 30:753-772

Rabalais NN, Turner RE, Diaz RJ, Justic D (2009) Global change and eutrophication of coastal waters. ICES J Mar Sci 66:1528-1537

Raffaelli D, Solan M, Webb TJ (2005) Do marine and terrestrial ecologists do it differently? Mar Ecol Prog Ser 304: 283-289

Rittel HWJ, Webber MM (1973) Dilemmas in a general theory of planning. Policy Sci 4:155-169

SAFMC (South Atlantic Fishery Management Council) (2010) Fishing regulations for South Atlantic federal waters. SAFMC, North Charleston, SC. Available at www.safmc. net/LinkClick.aspx?fileticket=KMfgAnrh1I0 \%3d\&tabid= 248 (accessed on 10 November 2010)

Salomon AK, Gaichas SK, Shears NT, Smith JE, Madin EMP,

Submitted: November 22, 2010; Accepted: March 15, 2011
Gaines SD (2010) Key features and context-dependence of fishery-induced trophic cascades. Conserv Biol 24: 382-394

> Sleasman K (2009) Coordination between Monroe County and the Florida Keys National Marine Sanctuary (FKNMS). Ocean Coast Manag 52:69-75

Smith SG, Ault JS, Bohnsack JA, Harper DE, Luo JG, McClellan DB (2011) Multispecies survey design for assessing reef-fish stocks, spatially explicit management performance, and ecosystem condition. Fish Res 109:25-41

Stergiou KI, Browman HI (2005) Bridging the gap between aquatic and terrestrial ecology. Mar Ecol Prog Ser 304: 271-307

- Turner RE, Rabalais NN (1991) Change in Mississippi River water quality this century. Bioscience 41:140-147

$>$ Turner RE, Rabalais NN, Justic D (2008) Gulf of Mexico hypoxia: alternate states and a legacy. Environ Sci Technol 42:2323-2327

USGS (United States Geological Survey) (2003) A summary report of sediment processes in Chesapeake Bay and watershed. Water-Resources Investigations Report 034123 USGS, New Cumberland, PA. Available at www. mgs.md.gov/coastal/pub/wrir03-4123.pdf (accessed on 10 November 2010)

- Wahle RA, Steneck RS (1991) Recruitment habitats and nursery grounds of the American lobster Homarus americanus-a demographic bottleneck. Mar Ecol Prog Ser 69: $231-243$

Proofs received from author(s): June 29, 2011 